\section{Clostridium difficile Plasmid Isolation as an Epidemiologic Tool}

\author{
C. Clabots ${ }^{1 *}$, S. Lee ${ }^{3}$, D. Gerding ${ }^{1,2}$, \\ M. Mulligan ${ }^{4}$, R. Kwok ${ }^{4}$, D. Schaberg ${ }^{5}$, \\ R. Fekety ${ }^{5}$, L. Peterson ${ }^{1,2}$
}

\begin{abstract}
A large hospital outbreak of Clostridium difficile diarrhea at the Minneapolis Veterans Administration Medical Center (MVAMC) was studied by plasmid profile typing. Plasmids were obtained from $\mathbf{3 0}$ (37\%) of 82 clinical isolates from MVAMC patients and $10(67 \%)$ of 15 non-MVAMC isolates. While bacteriophage plus bacteriocin typing and polyacrylamide gel electrophoresis (PAGE) plus bacterial agglutination typing proved more universally applicable, plasmid profiles may be useful for tracing isolated epidemic outbreaks, reinfections and relapses caused by plasmid-bearing strains.
\end{abstract}

Clostridium difficile and its toxins have been linked etiologically to antibiotic-associated pseudomembranous colitis (1). Outbreaks of Clostridium difficile disease have occurred at the Minneapolis Veterans Administration Medical Center (MVAMC) (2) and have been reported at other institutions (3). The epidemiological study of the disease has been hindered by the lack of a universally acceptable typing method.

The purpose of this report was to examine the potential of plasmid profile analysis as an epidemio. logic tool and to compare bacteriophage plus bacteriocin (B/B, 4), PAGE plus bacterial agglutination typing (PAGE/serotyping, 5) and plasmid profiles of MVAMC and the University of Minnesota Clostridium difficile strains. Plasmid profiles of isolates from the West Los Angeles VAMC and University of Michigan were compared to strains from the MVAMC.

${ }^{1}$ Infectious Disease Section, Medical Service, Veterans Administration Medical Center, Minneapolis, Minnesota 55417 , USA.

${ }^{2}$ Infectious Disease Section, Medical Service, and the Microbiology Section, Labotatory Service, Veterans Administration Medical Center, Minneapolis, Minnesota 55417, USA.

${ }^{3}$ Department of Genetics, Stanford University School of Medicine, Stanford, California 94305, USA.

${ }^{4}$ Medical and Research Services, Veterans Administration Medical Center, and UCLA, Los Angeles, California, 90073, USA.

${ }^{5}$ Infectious Disease Section, Department of Medicine, University of Michigan Medical School, Ann Arbor, Michigan, 48109, USA.
Materials and Methods. Ninety-seven isolates were examined for plasmids. The first group of Clostridium difficile strains were 82 MVAMC clinical isolates chosen randomly from a 1982-1984 collection of approximately 400 isolates stored $1-32$ months prior to plasmid analysis. The second group consisted of 15 out-of-hospital isolates, nine from the West Los Angeles VAMC, and six from the University of Michigan. From the 82 MVAMC clinical isolates, thirteen strains isolated during December 1982. February 1983 were sent in triplicate to the West Los Angeles VAMC for typing by PAGE/serotyping (5). These same 13 plus 22 additional MVAMC isolates recovered in March-May, 1982 and nine isolates from the University of Minnesota Hospital (courtesy of C. Wells) were sent to the University of Michigan for $B / B$ typing (4). All isolates were recovered from stool samples using CCFA agar (6) incubated anaerobically for $48 \mathrm{~h}$ at $37^{\circ} \mathrm{C}$. Morphologically characteristic colonies were identified as Clostridium difficile by Gram stain and gas liquid chromatography (7). MVAMC isolates were subcultured to Chopped Meat Broth (CM) (Gibco Laboratories, USA) for storage.

Clostridium difficile DNA was extracted by a method modified from that of Portnoy et al. (8). Cells grown anaerobically for $24 \mathrm{~h}$ at $37^{\circ} \mathrm{C}$ in $400 \mathrm{ml}$ reduced BHI broth (Difco Laboratories, USA) were washed once in $15 \mathrm{ml}$ and resuspended in $1 \mathrm{ml}$ of reduced $20 \%(\mathrm{w} / \mathrm{v})$ sucrose. Lysozyme $(0.5 \mathrm{ml}$ of $30 \mathrm{mg} / \mathrm{ml})$ in reduced $20 \%$ sucrose was added and incubated for $30 \mathrm{~min}$ at $37^{\circ} \mathrm{C}$. Six milliliters of lysis buffer $(1 \%$ sodium dodecyl sulfate in $10 \mu \mathrm{M}$ TRIS and $1 \mu \mathrm{M}$ EDTA, (TE), pH-12.30) was added, mixed thoroughly, and incubated $30 \mathrm{~min}$ at $37^{\circ} \mathrm{C}$. All manipulations before the addition of the lysis buffer were performed under anaerobic conditions. Three milliliters of $2 \mathrm{M}$ TRIS, $\mathrm{pH} 7.0$, and $1.6 \mathrm{ml}$ of $5 \mathrm{M} \mathrm{NaCl}$ were added and incubated for 1-2 h on ice. Chromosomemembrane complexes were pelleted $(20,000 \times g)$ for $30 \mathrm{~min}$ and discarded. The supernatant received one volume of isopropanol and was stored $30 \mathrm{~min}$ at $-20^{\circ} \mathrm{C}$. DNA precipitate was centrifuged for $20 \mathrm{~min}$ $(3000 \times \mathrm{g}$ ) and dried for $30 \mathrm{~min}$ at room temperature. Plasmid DNA was purified from total nucleic acids by isopycnic banding in cesium chloride-ethidium bromide gradients (9). Plasmid DNA was separated by electrophoresis in $0.7 \%$ agarose gels using TRISacetate buffer, and run at $25 \mathrm{~V}(1.9 \mathrm{v} / \mathrm{cm})$ for $16 \mathrm{~h}$ (10). Strain 328 , a MVAMC clinical isolate bearing plasmids, was run as a plasmid-positive control. B/B typing was performed at the University of Michigan Hospital, Ann Arbor, Michigan (4) and PAGE/serotyping was performed at the West Los Angeles VAMC, Los Angeles, California (5). Statistical testing was done with the chi-square, Fisher's exact and Student's t test. 




Incidence of C.difficile-ossociated disease by quarter $(1982-1984)$ and hospital ward.

\section{Plasmid Negative Isolates}

Figure 1: Case incidence by quarter and hospital ward illustrating the isolates selected for plasmid analysis. Wards $5 \mathrm{~B}, 3 \mathrm{~A}$ and 32 are surgical wards and $6 \mathrm{AW}, 6 \mathrm{AE}, 6 \mathrm{~B}, 5 \mathrm{AW}$ and $4 \mathrm{AW}$ are medicine wards.

Results and Discussion. The incidence of Clostridium difficile-associated diarrhea and colitis between 1982 and 1984 by hospital ward and the isolates selected for study is presented in Figure 1. Forty $(41 \%)$ of 97 total isolation attempts yielded plasmids. Only 30 (37\%) of 82 MVAMC strains yielded plasmids, while $10(67 \%)$ of 15 out-of-hospital strains were plasmid positive $(\mathrm{p}<0.05)$. A band of approximately $6.4 \mathrm{~Kb}$ was discovered in $13(43 \%)$ of the 30 MVAMC plasmid-bearing strains and 2 of the 10 out-ofhospital strains ( $p$, N.S.).

A sample of plasmid profiles from strains of Clostridium difficile from the MVAMC is given in Figure 2. Considerable variability in the plasmid profiles of Clostridium difficile was found. Most organisms containing the $6.4 \mathrm{~Kb}$ band also contained a larger band plus 1 to 6 other bands. No clustering by time or space was observed for the $13(43 \%)$ of 30 isolates containing the $6.4 \mathrm{~Kb}$ band. However, six isolates with identical patterns consisting of the $6.4 \mathrm{~Kb}$ band and a larger band were isolated from four symptomatic patients and from two carriers (Figure 2, Lane C). Three isolates from symptomatic patients and one from a carrier were recovered within the same time period, but none of the strains were spatially related in the hospital. The plasmids of strains 275 and 290 also appeared to be identical
(Figure 2, Lanes D and E). The two strains were isolated one month apart and were obtained from the same patient with pseudomembranous colitis.

The 64 MVAMC plasmid-negative isolates were stored in CM significantly longer (mean $=19$ months) than the 30 MVAMC positive isolates (mean $=11$ months, $\mathrm{p}<0.01$ ). From the isolates stored for less than 18 months no difference in storage duration was found between 20 plasmid-positive and 22 plasmid-negative strains.

The set of thirteen isolates from December 1982 February 1983 had five distinct types with the B/B method and four types with the PAGE/serotyping (Table 1). Virtually complete correlation was noted except that one PAGE/serotyping category encompassed two B/B categories. Seven different B/B types were obtained from the set of nine University of Minnesota organisms and 22 MVAMC isolates recovered in March and May 1982. No PAGE/serotyping was performed on these isolates. Two new $B / B$ types were found in additional to the same five types found in the set of 13 MVAMC organisms isolated during December 1982 through February 1983. Four different $B / B$ types similar to those found at the MVAMC were obtained from the nine University of Minnesota isolates. Two of 22 MVAMC isolates were plasmid positive and had a similar B/B 


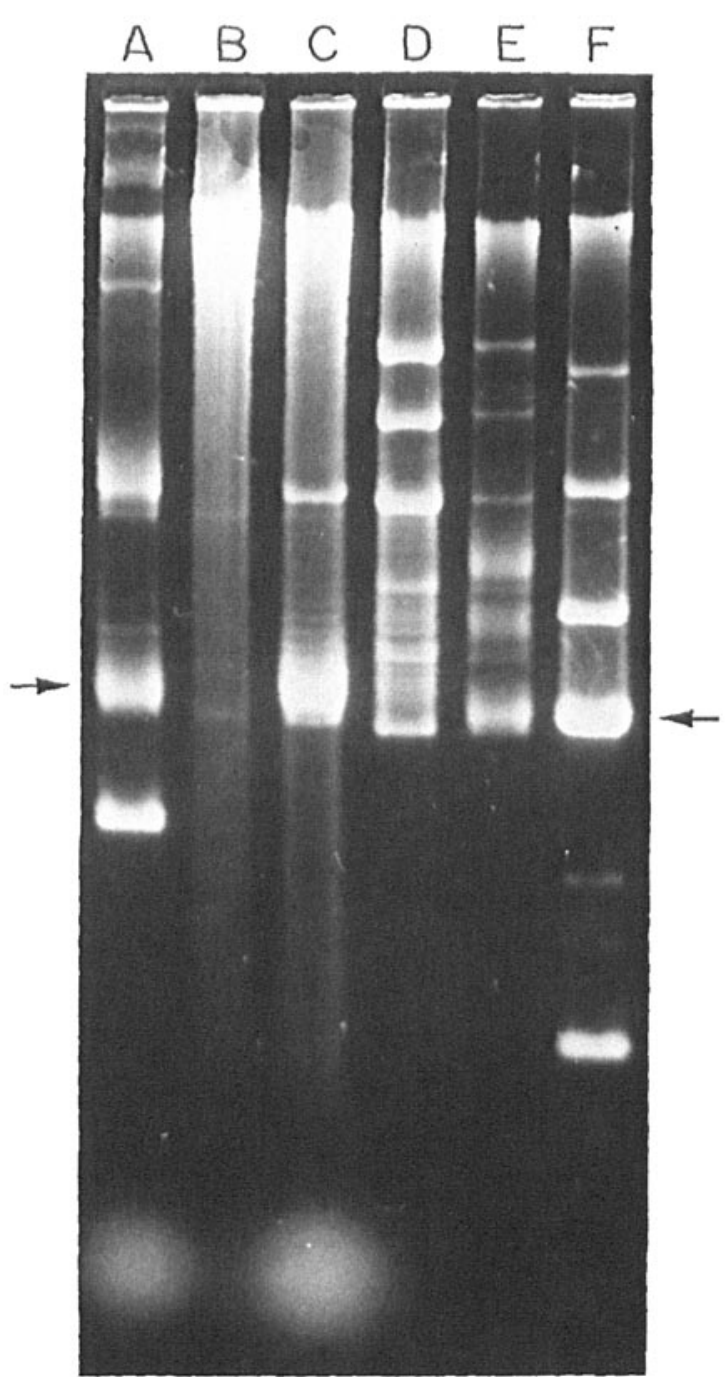

Figure 2: Agarose gel electrophoresis profiles of Clostridium difficile plasmids from MVAMC isolates with the common $6.4 \mathrm{~Kb}$ band. Lane A Clostridium difficile isolate 632 ; Lane $\mathrm{B}$ 528; Lane C 457; Lane D 290; Lane E 275; Lane F 328 (control strain). type $(16 / 17)$ but different plasmid profile types. Type $16 / 17$ occurred in $17(77 \%)$ of 22 MVAMC and one of nine University of Minnesota isolates.

$\mathrm{B} / \mathrm{B}$ and PAGE/serotyping methods were more successful than plasmid isolation in typing a larger number of MVAMC strains. B/B typing results suggest that a large proportion of the MVAMC cases in March-May 1982 may be due to an epidemic strain. Plasmids were obtained from only two isolates from the same time period. Many different strains were found by all three methods in time periods before and after March-May 1982 (Figure 1, Table 1). Good corselation between B/B and PAGE/serotyping methods and consistency in typing a limited number of duplicate blinded specimens confirmed that both methods may prove a reliable epidemiological tool.

The plasmid yield for isolates stored in $\mathrm{CM}$ less than 18 months was approximately $50 \%$ but storage in $\mathrm{CM}$ for longer than 18 months was associated with a significantly lower percentage of plasmid-positive isolates. This phenomenon could be explained by a loss of plasmids with time, or simply reflect a lower frequency of plasmid-containing Clostridium difficile strains from March-May 1982. A controlled study of plasmid positive isolates stored in $\mathrm{CM}$ will be required to determine if plasmid loss occurs in storage .

While B/B and PAGE/serotyping methods appear to be more universally applicable, plasmid profile typing may prove useful to trace isolated epidemic outbreaks and to address questions concerning individual relapses and reinfections. Continued epidemiologic investigation using these methods is needed in order to better understand the epidemiology of Clostridium difficile-associated disease and to control these increasingly frequent infections within hospitals and other health care facilities.

Table 1: Comparison of plasmid profile, PAGE/sero and B/B typing.

\begin{tabular}{|c|c|c|c|c|}
\hline Code & Date & Plasmid & PAGE/sero & $B / B$ \\
\hline A & 2 December 1982 & - & IC & not done \\
\hline$A$ & 8 December 1982 & - & $1 \mathrm{C}$ & B1811/810/1481/1320/1700 \\
\hline B & 1 January 1983 & - & $1 \mathrm{C}$ & B1811/810/1481/1320/1700 \\
\hline $\mathrm{C}$ & 28 February 1983 & - & $2 A$ & B1811/810/1481/1320/1700/1537 \\
\hline C & 2 March 1983 & - & $2 \mathrm{~A}$ & $\mathrm{~B} 1811 / 810 / 1481 / 1320 / 1700 / 1537$ \\
\hline $\mathfrak{D}$ & 2 February 1983 & - & $2 A$ & $\mathrm{~B} 83 / 778 / 809 / 1995 / 33 \mathrm{~A} / 806$ \\
\hline $\mathrm{D}$ & 24 February 1983 & - & $2 \mathrm{~A}$ & $\mathrm{~B} 83 / 778 / 809 / 1995 / 33 \mathrm{~A} / 806$ \\
\hline$E$ & 26 January 1983 & + & $2 B$ & B 1537 \\
\hline E & 27 February 1983 & + & $2 B$ & B1537 \\
\hline A & 27 December 1982 & - & $3 D$ & $16(17$ and $19 \mathrm{wk})$ \\
\hline$F$ & 3 December 1982 & - & $3 D$ & $16(17$ and $19 \mathrm{wk})$ \\
\hline$F$ & 15 December 1982 & - & $3 \mathrm{D}$ & not done \\
\hline$G$ & 26 December 1982 & - & $3 D$ & 16 \\
\hline
\end{tabular}

$\mathrm{PAGE}=$ polyacrylamide gel clectrophoresis; $\mathrm{B} / \mathrm{B}=$ bacteriophage plus bacteriocin. 


\section{Acknowledgement}

This wark was supported by the Veterans Administration, Marion Laboratories, Kansas City, MO.

\section{References}

1. Bartlett, J. G., Chang, T. W., Gurwith, M., Gorbach, S. L., Onderdonk, A. B.: Antibiotic-associated pseudomembranous colitis due to toxin-producing clostridia. New England Journal of Medicine 1981, 298: 531 534.

2. Gerding, D. N., Olson, M. M., Peterson, L. R., Teasley, D. G., Gebhard, R. L., Schwartz, M. L., Lee, J. T., Jt.: Clostridium difficile-associated diarrhea and colitis in adults: A prospective case-controlled epidemiologic study. Archives of Internal Medicine 1986, 146: 95100.

3. Cumming, A. A., Thomson, B. J., Sharp, J., Poxton, I. R., Fraser, A. G.: Diarrhoea due to Clostridium difficilie-associated with antibiotic treatment in patients receiving dialysis: the role of cross infections. British Medical Journal 1986, 292: 238-239.
4. Sell, T. L., Schaberg, D. R., Fekety, F. R.: Bacteriophage and bacteriocin typing scheme for Clostridium difficile. Journal of Clinical Microbiology 1983, 17: $1148-1152$.

5. Mulligan, M. E., Halebian, S., Kwok, R. Y. Y., Cheng, W. C., Finegold, S. M., Anselmo, C. R., Gerding, D. N., Peterson, L. R.: Bacterial agglutination and polyacrylamide gel electrophoresis for typing Clostridium difficile. Journal of Infectious Diseases 1986, 153: $267-271$.

6. George, W. L., Sutter, V. L., Citron, D., Finegold, S. M.: Selective and differential medium for isolation of Clostridium difficile. Journal of Clinical Microbiology 1979, 9: 214-219.

7. Holdeman, L. V., Moore, W. E. C., Cato, E. P. (ed.): Anerobe Laboratory Manual. Virginia Polytechnic Institute and State University, Blacksburg, VA, 1977.

8. Portnoy, D. A., Moseley, S. L., Falkow, S.: Characterization of plasmids and plasmid-associated determinants of Yersinia enterocolitica pathogenesis. Infection and Immunity $1981,31: 775-782$.

9. Radloff, R. W., Bauer, W., Vinograd, J.: A dyc-buoyantdensity method for the detection and solation of closed circular duplex DNA: the closed circular DNA in HeLa cells. Proceedings of the National Academy of Science of the USA $1967,57: 1514-1521$.

10. Maniatis, T., Fritsch, E. F., Sambrook, J. (ed.): Molecular Cloning. Cold Spring, Cold Spring Laboratories, 1982 , p. $150-162$. 